\title{
PRODUCTION OF CARBON MONOXIDE BY BACTERIA OF THE GENERA PROTEUS AND MORGANELLA
}

\author{
ATSUNOBU HAYASHI, ${ }^{1}$ HIROSHI TAUCHI, AND SEIICHI HINO ${ }^{2}$ \\ Botanical Institute, Faculty of Science, Hiroshima \\ University, Naka-ku, Hiroshima 730, Japan
}

(Received July 2, 1985)

\begin{abstract}
A bacterium, isolated from human saliva, produced carbon monoxide (CO) when cultured in nutrient broth containing hemin or hemoglobin. The production of $\mathrm{CO}$ was detected by gas chromatography, and confirmed by gas chromatography-mass spectrometry and spectrophotometry which revealed an absorption spectrum of CO-hemoglobin. The isolated bacterium was identified as a strain of Proteus vulgaris. Survey of 4 IFO strains of $P$. vulgaris, 1 IFO strain of $P$. mirabilis and 2 IFO strains of Morganella morganii (received as $P$. morganii) showed that all the 7 strains had the ability to produce $\mathrm{CO}$. They produced detectable amounts of $\mathrm{CO}$ when cultured in a glucose-peptone medium or in the nutrient broth without the addition of heme compound, and the $\mathrm{CO}$ production was distinctly enhanced by the addition of hemin. Morganella morganii IFO 3168, the most active $\mathrm{CO}$ producer among the strains tested, produced about $2 \mu \mathrm{mol}$ of $\mathrm{CO}$ in the absence of hemin and $6 \mu \mathrm{mol}$ of $\mathrm{CO}$ in the presence of $3 \mu \mathrm{mol}$ of hemin. The result suggests that $\mathrm{CO}$ production by the Morganella strain is different from the $\mathrm{CO}$ production by mammalian tissues where $1 \mathrm{~mol}$ of protoheme is degraded to $1 \mathrm{~mol}$ each of $\mathrm{CO}$ and biliverdin.
\end{abstract}

Small amounts of $\mathrm{CO}$ are produced in normal human tissues where hemoglobin is degraded to equimolar amounts of biliverdin and CO. The degradation is catalyzed by microsomal heme oxygenase ( 1 ) and the $\mathrm{CO}$ is produced by the oxidation of $\alpha$-methene bridge carbon of the porphyrin ring (2). Some reports showed that abnormally large amounts of $\mathrm{CO}$ were produced in some tissues of post-mortem human bodies $(3,4)$. The cause of the abnormal formation is unknown and we suspected that bacterial activity might be responsible for the formation. ENGEL et al. observed CO formation by hemolytic strains of Bacillus cereus

1 On leave from the Scientific Investigation Research Laboratory, Hiroshima Prefectural Police Headquarters, Hiroshima, Japan.

2 To whom correspondence should be addressed. 
and Streptococcus mitis when heme (5) or cobalamin compounds (6) were added to the culture media. No further report has appeared concerning the CO formation by these bacteria.

In this study we isolated a CO-producing bacterium from human saliva. Since we identified the bacterium to be a strain of Proteus vulgaris, we further examined some bacterial strains of the genera Proteus and Morganella, and found that all of the strains had the ability to produce $\mathrm{CO}$.

\section{MATERIALS AND METHODS}

Organisms. A CO-producing bacterium was isolated from human saliva by the procedure described later. Beside the isolated strain, several strains of Proteus vulgaris, P. mirabilis, Morganella morganii, Pseudomonas aeruginosa and Bacillus cereus were obtained from the Institute for Fermentation, Osaka. In addition, Citrobacter freundii AHU (Faculty of Agriculture, Hokkaido University, Sapporo) 1533, Klebsiella pneumoniae M5a1 (7), Escherichia coli B, E. coli K12 were included among the test organisms. Morganella morganii IFO 3168 and IFO 3848 were received as Proteus morganii IFO 3168 and IFO 3848, and Citrobacter freundii AHU 1533 as Escherichia freundii AHU 1533. In this paper, these bacteria are described as Morganella morganii and Citrobacter freundii, according to the designations in Bergey's Manual of Systematic Bacteriology (8).

Culture conditions. Bacteria were precultured for $18 \mathrm{hr}$ at $30^{\circ} \mathrm{C}$ in a nutrient broth containing meat extract (Kyokuto) $10 \mathrm{~g}$, Polypeptone (Wako) $10 \mathrm{~g}$ and $\mathrm{NaCl}$ $1.5 \mathrm{~g}$ in $1,000 \mathrm{ml} \mathrm{H}_{2} \mathrm{O}(\mathrm{pH}$ 7.2). The nutrient broth was used in most of the main cultures, but in some experiments semisynthetic media were also used which contained $\mathrm{Na}_{2} \mathrm{HPO}_{4} \cdot 12 \mathrm{H}_{2} \mathrm{O} 24 \mathrm{~g}, \mathrm{KH}_{2} \mathrm{PO}_{4} 4.5 \mathrm{~g},\left(\mathrm{NH}_{4}\right)_{2} \mathrm{SO}_{4} 1.0 \mathrm{~g}, \mathrm{MgSO}_{4} \cdot 7 \mathrm{H}_{2} \mathrm{O}$ $100 \mathrm{mg}, \mathrm{CaCl}_{2} 3 \mathrm{mg}, \mathrm{FeSO}_{4} \cdot 7 \mathrm{H}_{2} \mathrm{O} 0.5 \mathrm{mg}$, glucose $10 \mathrm{~g}$, and Polypeptone or casamino acids (vitamin free, Nissan) $10 \mathrm{~g}$ in 1,000 $\mathrm{ml} \mathrm{H}_{2} \mathrm{O}(\mathrm{pH} 7.0$ ). Blood-containing nutrient broth was prepared by adding sterile defibrinated horse blood (Nippon Seibutsu Zairyo Co., Ltd.) to the nutrient broth.

To test the effect of hemin on CO evolution, hemin (Sigma, Type III) was dissolved in $0.1 \% \mathrm{NaOH}$, and $1 \mathrm{ml}$ of either sterile hemin solution or $0.1 \% \mathrm{NaOH}$ solution was added to $9 \mathrm{ml}$ of the culture medium in a 50-ml Erlenmeyer flask; the addition of $\mathrm{NaOH}$ did not change the $\mathrm{pH}$ of the media significantly. After inoculation of $0.1 \mathrm{ml}$ of the preculture, the flask was sealed with a silicon stopper. In the central portion of the stopper a hole was bored and a rubber plug, used to inject gas samples by a needle into a gas chromatograph, was tightly inserted in the hole. The flasks were shaken at $30^{\circ} \mathrm{C}$ on a reciprocating shaker at $120 \mathrm{rpm}$ with an amplitude of $5 \mathrm{~cm}$.

After incubation, most of the culture flasks showed negative pressure, probably due to consumption of oxygen by bacteria. Flasks were brought to a laboratory room and after temperature equilibrium, pure helium was added to the 
flask by a syringe through the rubber plug to make slightly positive pressure; the amount of added helium was generally between 1 to $5 \mathrm{ml}$ and the gas volume of the flask was about $55 \mathrm{ml}$. It was necessary to take precautions against contamination of $\mathrm{CO}$ from laboratory sources, particularly from flames of coal gas or from alcohol lamps. A considerable amount of $\mathrm{CO}$ was produced after autoclaving the culture media containing both glucose and hemin, therefore we sterilized hemin solutions separately from the other components in the culture media.

Analysis of $\mathrm{CO}$. In most of the present experiments, $\mathrm{CO}$ was analyzed by a Shimadzu gas chromatograph model GC-6AI with a thermal conductivity detector and a $2.1 \mathrm{~m}$ Molecular Sieve 5A (60-80 mesh) column. The column temperature was set at $100^{\circ} \mathrm{C}$ and helium was used as a carrier gas with a flow rate of $20 \mathrm{ml} /$ min. One $\mathrm{ml}$ of gas sample was withdrawn from the culture flasks and injected into the gas chromatograph for analysis of $\mathrm{CO}$. For quantitative analysis, various amounts of pure $\mathrm{CO}$ gas were injected by a microsyringe and a standard curve was drawn between the amount of $\mathrm{CO}$ and height of the peak on the recorder at the retention time of $\mathrm{CO}$. Amounts of $\mathrm{CO}$ dissolved in culture solutions were not corrected, since solubility of $\mathrm{CO}$ in water is low.

Three other methods were used for qualitative detection of $\mathrm{CO}$ : For a preliminary survey of CO-producing bacteria, a Kitagawa precision $\mathrm{CO}$ detector tube was used, which changes color from yellow to pale blue when CO concentration is in a range of 5 to $50 \mathrm{ppm}$. The detector tube set was purchased from Komyo Rikagaku Kogyo Co., Kawasaki, Japan. Formation of CO-hemoglobin from hemoglobin was detected with a Shimadzu spectrophotometer model UV200. Formation of $\mathrm{CO}$ was also confirmed by gas chromatography-mass spectrometry with a Shimadzu Auto GCMS-6020 and a Molecular Sieve 5A column ( $2 \mathrm{~m})$, by the procedure described by Kojima et al. (4).

Identification of the isolated bacteria. Cells were grown on nutrient agar at $30^{\circ} \mathrm{C}$ for microscopic observations such as cell shape, cell size and gram stain. Gram stain was performed by the Hucker modification. For observation of flagella, cells were grown in the nutrient agar at $25^{\circ} \mathrm{C}$ and observed under a light microscope after staining by the Nishizawa and Sugawara method (9). The following biochemical tests were performed at $36^{\circ} \mathrm{C}$. Enterotube II, Roche, purchased from the Japan Roche Co. Ltd., was used for tests of acid and gas formation from glucose, and acid formation from adonitol, lactose, arabinose, sorbitol and dulcitol. The same tube was also used for the Voges-Proskauer reaction, citrate utilization, indole production, $\mathrm{H}_{2} \mathrm{~S}$ production, urease, phenylalanine deaminase, lysine and ornithine decarboxylase. Gas formation from glucose was also examined with the Durham tube. Acid formation from sucrose, xylose, maltose and mannose were examined in semi-solid peptone water, to which $1 \%$ carbohydrate and a $0.01 \%$ bromthymol blue were added. Tests for cytochrome oxidase and catalase followed the methods described by Holding and ColleE (10). 


\section{RESULTS AND DISCUSSION}

\section{Isolation of $\mathrm{CO}$-producing bacteria}

We were able to isolate CO-producing bacteria from human saliva after failure to isolate such bacteria from some other natural sources. About $0.1 \mathrm{ml}$ of human saliva was added to $10 \mathrm{ml}$ of the nutrient broth containing $10 \%$ defibrinated horse blood, and after incubation for $18 \mathrm{hr}$, gas samples from the culture flasks were analysed for $\mathrm{CO}$ by gas chromatography. Since the result showed the presence of $\mathrm{CO}, 0.1 \mathrm{ml}$ of the culture solution was added to $10 \mathrm{ml}$ of the nutrient broth containing $10 \mu \mathrm{mol}$ of hemin, and after cultivation for $18 \mathrm{hr}$, cells were subcultured to fresh hemin-containing broth. Final culture solutions were streaked on nutrient agar plates and colonies were isolated and transferred to nutrient agar slants.

After the isolated bacterial cells had been cultured in hemin-containing nutrient broth, gas samples from the culture flasks were analysed by gas chromatography. The chromatogram showed the CO-peak at a retention time of about $3.5 \mathrm{~min}$; peaks of $\mathrm{O}_{2}$ and $\mathrm{N}_{2}$ appeared at about $1.0 \mathrm{~min}$ and $1.5 \mathrm{~min}$, respectively (Fig. 1). Analysis by gas chromatography-mass spectrometry of the gas samples from culture flasks showed 3 similar peaks on the total ion current chromatogram, and the

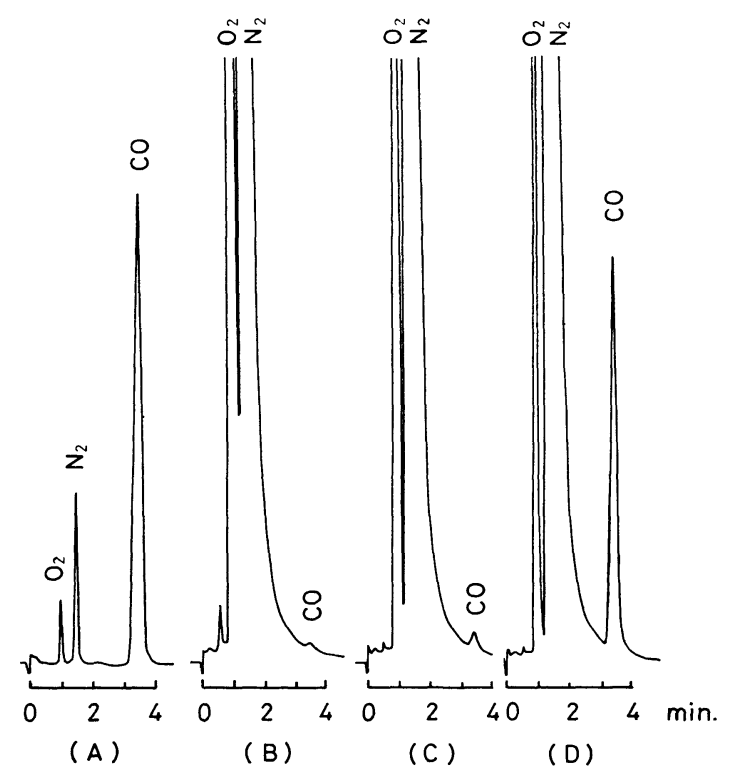

Fig. 1. Gas chromatograms showing production of $\mathrm{CO}$ by isolated bacteria.

(A) Air and standard CO, (B) Gas sample from uninoculated control (nutrient broth containing $10 \mu \mathrm{mol}$ of hemin per $10 \mathrm{ml}$ ), (C) Gas sample from inoculated culture (nutrient broth without addition of hemin), (D) Gas sample from inoculated culture (nutrient broth containing $10 \mu \mathrm{mol}$ of hemin per $10 \mathrm{ml}$ ). 
Table 1. Characteristics of the isolated strain.

\begin{tabular}{lclc}
\hline Cell shape & Rods & Gas from glucose & - \\
Cell size & & Acid from \\
$\quad$ Width, $\mu \mathrm{m}$ & $0.4-0.6$ & Glucose & + \\
$\quad$ Length, $\mu \mathrm{m}$ & $0.8-2.0$ & Mannose & - \\
Gram reaction & - & Sucrose & + \\
Motility & + & Lactose & - \\
Swarming & + & Maltose & + \\
Flagella & Peritrichous & Arabinose & - \\
Oxidase test & - & Xylose & + \\
Catalase & + & Adonitol & - \\
Amino acids & & Sorbitol & - \\
$\quad H_{2}$ S production & - & Dulcitol & - \\
$\quad$ Lysine decarboxylase & - & Mannitol & - \\
$\quad$ Ornithine decarboxylase & - & Citrate utilization & + \\
$\quad$ Phenylalanine deaminase & + & Voges-Proskauer test & - \\
$\quad$ Urease & + & & \\
$\quad$ Indole production & + & & \\
\hline
\end{tabular}

sample of the peak corresponding to $\mathrm{CO}$ showed base peak ion, $m / z 28$, and a small ion, $m / z 29$, in the mass spectrum; this feature is quite similar to that of pure CO.

The isolated bacteria also produced $\mathrm{CO}$ when cultured in nutrient broth containing defibrinated horse blood. The $\mathrm{CO}$ formation was confirmed by gas chromatographic analysis of the gas sample from culture flasks and also by spectrophotometric analysis. When the culture solutions were centrifuged to remove cells, the supernatants from inoculated cultures showed absorption maxima of CO-hemoglobin at 570 and $540 \mathrm{~nm}$, while the supernatants from the uninoculated controls showed maxima of $\mathrm{O}_{2}$-hemoglobin at 578 and $542 \mathrm{~nm}$.

\section{Identification of the isolated strain}

The taxonomic characteristics of the isolated bacterium were examined and the result is shown in Table 1 . The bacterium is a facultatively anaerobic gramnegative rod, and is oxidase-negative. The cells are motile with peritrichous flagella and are positive in phenylalanine deaminase and urease. These results show that the bacterium should be classified among the genera Proteus, Providencia or Morganella. Swarming of cells was suggested by occasional halos around the stroke colonies on the surface of agar plates. Further characteristics listed in Table 1 coincides well with those of $P$. vulgaris listed in the Bergey's Manual of Systematic Bacteriology (8), except the ability to produce gas from glucose. Our tests with both Durham tubes and semi-solid nutrient agar showed that the isolated strain is negative in gas production. Although typical $P$. vulgaris is described as positive, gas production by $P$. vulgaris is generally weak and 11 to $24 \%$ of $P$. vulgaris strains are reported to be negative (8). Therefore we concluded that the isolated organism is a strain of $P$. vulgaris. 
Table 2. CO production by strains of Proteus and Morganella ( $\mu \mathrm{mol} \mathrm{CO}$ per culture flask).

\begin{tabular}{|c|c|c|c|c|}
\hline \multirow{3}{*}{ Bacteria } & \multicolumn{4}{|c|}{ Culture medium } \\
\hline & \multicolumn{2}{|c|}{ Nutrient broth } & \multicolumn{2}{|c|}{ Glucose peptone } \\
\hline & without hemin & with hemin & without hemin & with hemin \\
\hline Sterile control & 0.05 & 0.14 & 0.00 & 0.07 \\
\hline $\begin{array}{l}\text { P. vulgaris } \\
\text { (isolated strain) }\end{array}$ & 0.36 & 2.12 & 0.12 & 1.57 \\
\hline $\begin{array}{l}P . \text { vulgaris } \\
\text { IFO } 3045\end{array}$ & 0.50 & 0.80 & 0.22 & 1.55 \\
\hline $\begin{array}{l}\text { P. vulgaris } \\
\text { IFO } 3167\end{array}$ & 0.61 & 0.87 & 0.15 & 1.17 \\
\hline $\begin{array}{l}\text { P. vulgaris } \\
\text { IFO } 3851\end{array}$ & 0.63 & 2.71 & 0.22 & 1.67 \\
\hline $\begin{array}{l}\text { P. vulgaris } \\
\text { IFO } 3988\end{array}$ & 0.45 & 0.80 & 0.39 & 2.16 \\
\hline $\begin{array}{l}\text { P. mirabilis } \\
\text { IFO } 3849\end{array}$ & 0.38 & 1.98 & 0.12 & 1.00 \\
\hline $\begin{array}{c}\text { M. morganii } \\
\text { IFO } 3168\end{array}$ & 2.03 & 6.10 & 0.93 & 5.99 \\
\hline $\begin{array}{l}\text { M. morganii } \\
\text { IFO } 3848\end{array}$ & 0.75 & 2.13 & 0.34 & 3.39 \\
\hline
\end{tabular}

Cells were grown for $24 \mathrm{hr}$ at $30^{\circ} \mathrm{C}$ in nutrient broth or glucose-peptone medium with or without addition of $3 \mu \mathrm{mol}$ of hemin. CO production is expressed as $\mu \mathrm{mol} \mathrm{CO}$ per culture flask (gas volume: $55 \mathrm{ml}$ ).

\section{CO production by strains of Proteus and Morganella}

Strains of $P$. vulgaris IFO 3045, IFO 3167, IFO 3851, IFO 3988, $P$. mirabilis IFO 3849, Morganella morganii IFO 3168 and IFO 3848 were tested for their ability to produce CO. Cells were cultured in $10 \mathrm{ml}$ of the nutrient broth with or without addition of $3 \mu \mathrm{mol}$ hemin. After incubation for $24 \mathrm{hr}$, concentrations of $\mathrm{CO}$ in the gas phase of the culture flasks were analyzed by gas chromatography and the total amounts of $\mathrm{CO}$ produced in the flasks were calculated. Uninoculated controls were run in parallel. In the present experiments, the lower limit for detection of $\mathrm{CO}$ was about $0.02 \mu \mathrm{l}$ per $\mathrm{ml}$ of the gas in the culture flask or about $0.05 \mu \mathrm{mol}$ per total gas volume of the flask (volume: $55 \mathrm{ml}$ ). Table 2 shows that all the strains of $P$. vulgaris, $P$. mirabilis and $M$. morganii produced $\mathrm{CO}$ when cultured in the nutrient broth, and the activity of $\mathrm{CO}$ production was different among the strains. Production of $\mathrm{CO}$ was evident even when the bacteria were cultured in the nutrient broth without the addition of hemin. Since the meat extract, used for preparation of the nutrient broth, may contain some heme compounds, the experiments were repeated with the glucose-peptone medium. The results are included in Table 2. The production of $\mathrm{CO}$ from hemin-free glucose-peptone medium is evident with most of the strains, although the production is slight with $P$. vulgaris IFO 3167 and $P$. mirabilis IFO 3849. Results similar to those with the 
Table 3. CO production by other bacteria.

\begin{tabular}{lcc}
\hline \multirow{2}{*}{ Bacteria } & \multicolumn{2}{c}{ Nutrient broth } \\
\cline { 2 - 3 } & without hemin & with hemin \\
\hline Sterile control & 0.00 & 0.04 \\
Pseudomonas aeruginosa & 0.04 & 0.08 \\
Bacillus cereus IFO 3132 3445 & 0.03 & 0.26 \\
Klebsiella pneumoniae M5a1 & 0.03 & 0.08 \\
Citrobacter freundii AHU 1533 & 0.00 & 0.08 \\
Escherichia coli B & 0.07 & 0.11 \\
Escherichia coli K12 & 0.14 & 0.14 \\
\hline
\end{tabular}

See the legend to Table 2.

glucose-peptone medium were obtained with the medium containing glucose and vitamin-free casamino acids.

ENGEL et al. (5) reported that hemolytic strains of Streptococcus mitis and Bacillus cereus produced $\mathrm{CO}$ only when cultured in the presence of heme compounds, and the amount of $\mathrm{CO}$ produced from $25 \mathrm{mg}$ of hemoglobin (equivalent to $1.5 \mu \mathrm{mol}$ of heme) was $1.5 \mu \mathrm{mol}$ for the B. cereus and $0.5 \mu \mathrm{mol}$ for the $S$. mitis after 7 days culture. In the present experiment, strains of Proteus and Morganella produced $\mathrm{CO}$ without the addition of heme compounds, although $\mathrm{CO}$ formation was distinctly enhanced by the presence of heme compounds. The increased amount of $\mathrm{CO}$ production by the addition of $3 \mu \mathrm{mol}$ hemin to the culture of $M$. morganii IFO 3168 was about $5 \mu \mathrm{mol}$. The result indicates that more than $1 \mathrm{~mol}$ of $\mathrm{CO}$ was produced from $1 \mathrm{~mol}$ of hemin. Since $1 \mathrm{~mol}$ of $\mathrm{CO}$ is produced when $1 \mathrm{~mol}$ hemin is cleaved to biliverdin by heme oxygenase, $M$. morganii IFO 3168 either produces $\mathrm{CO}$ by further cleavage of biliverdin molecule or produces $\mathrm{CO}$ by a process different from heme oxygenase. The production of $\mathrm{CO}$ without the addition of hemin supports the second possibility.

Table 3 shows the results of a survey for the activity of $\mathrm{CO}$ evolution by Pseudomonas aeruginosa, Bacillus cereus and 3 species of the enterobacteria. Low but reproducible $\mathrm{CO}$ evolution was detected with $E$. coli $\mathrm{K} 12$ and $B$. cereus IFO 3132. The production of $\mathrm{CO}$ by $B$. cereus in the presence of hemin is in agreement with the report by ENGEL et al. (5).

We are grateful to Prof. T. Kojima and Dr. M. Yashiki, Hiroshima University School of Medicine, for analyses by gas chromatography-mass spectrometry.

\section{REFERENCES}

1) R. Tenhunen, H. S. Marver, and R. Schmid, Proc. Natl. Acad. Sci. U.S.A., 61, 748 (1968).

2) S. A. Landaw, E. W. Callahan, Jr., and R. SChmid, J. Clin. Invest., 49, 914 (1970).

3) J. A. Beeley and W. Harvey, J. Forensic Sci. Soc., 13, 297 (1973).

4) T. Kojima, Y. Nishiyama, M. Yashiki, and I. Une, Forensic Sci. Int., 19, 243 (1982). 
5) R. R. Engel, J. M. Matsen, S. S. Chapman, and S. Schwartz, J. Bacteriol., 112, 1310 (1972).

6) R. R. Engel, S. Modler, J. M. Matsen, and Z. J. Petryka, Biochim. Biophys. Acta, 313, 150 (1973).

7) M. C. Mahl, P. W. Wilson, M. A. Fife, and W. H. Ewing, J. Bacteriol., 89, 1482 (1965).

8) N. R. Krieg and J. G. Holt, In Bergey's Manual of Systematic Bacteriology, 1st ed., Vol. 1, Williams \& Wilkins Co., Baltimore (1984).

9) Tokyo Daigaku Ikagaku Kenkyujo Gakuyukai (ed.), Saikingaku Jissyu Teiyo, 5th ed., Maruzen, Tokyo (1976), p. 250.

10) A. J. Holding and J. G. Collee, In Methods in Microbiology, Vol. 6A, ed. by J. R. Norris and D. W. Ribbons, Academic Press, London (1971), p. 1. 